Zagazig J. Agric. Res., Vol. 43 No. (2) 2016

http:/www.journals.zu.edu.eg/journalDisplay.aspx? Journalld=1\&queryType=Master

\title{
EFFECT OF NITROGENOUS FERTILIZATION AND WHEY PROTEIN HYDROLYSATES ON GROWTH, PRODUCTIVITY, ANTIOXIDANTS AND STORABILITY OF SWEET POTATO GROWN IN SANDY SOIL
}

\author{
El-Sayed E. Abou El-Khair ${ }^{1 *}$ and A. Osman ${ }^{2}$ \\ 1. Potato and Vegetatively Propagated Veg. Res. Dept., Hort. Res. Inst., Agric. Res. Cent., Egypt \\ 2. Biochem. Dept, Fac. Agric., Zagazig Univ., Egypt
}

\begin{abstract}
This work was carried out during the two successive summer seasons of 2013 and 2014 at a Private Vegetable Farm in El-Khattara Distract, Sharkia Governorate, Egypt, to study the effect of different nitrogen rates and whey protein hydrolysates (WPH) concentrations as foliar application on growth, enzymes, antioxidants, yield, tuber root quality and storability of sweet potato cv. Buregard under sandy soil conditions using drip irrigation system. Fertilizing sweet potato plants cv. Buregard grown in sandy soil with $\mathrm{N}$ at $60 \mathrm{~kg} / \mathrm{fad}$., and foliar spray with $0.15 \% \mathrm{WPH}$ increased number of branches/ plant, leaf area/plant and shoots dry weight/plant, N, P and K uptake by shoots, average weight of tuber roots, marketable yield and total yield, TSS and total sugars as well as improved storability of tuber roots of sweet potato. Whereas, fertilizing plants with $80 \mathrm{~kg} \mathrm{~N} / \mathrm{fad}$., and spraying with $0.15 \%$ whey protein increased vine length, total chlorophylls in leaf tissues, peroxidase enzyme and antioxidants in shoots, starch content in tuber roots of sweet potato. On the other side, the highest concentration of glutathione oxidase enzyme in shoot and carotene content in tuber roots were recorded by the interaction treatment between $40 \mathrm{~kg} \mathrm{~N} / \mathrm{fad}$., and spraying with $0.15 \%$ whey protein. The study recommends by using nitrogen fertilizer at $60 \mathrm{~kg} / \mathrm{fad}$., and spraying with $0.15 \%$ whey protein to increase sweet potato yield grown in sandy soil.
\end{abstract}

Key words: Sweet potato, nitrogen, whey protein, enzymes, antioxidants, yield and storability.

\section{INTRODUCTION}

Sweet potato (Ipomoea batatas L.) which belongs to the family Convolvulaceae is becoming the most widely distributed root crop in most developing countries.

Nitrogen is an important factor in determining the yield and nutrient composition of root tubers, especially sweet potato. Nitrogen application to sweet potato was shown to linearly increase dry matter content, caroten and protein content of sweet potato (Constantin et al., 1984). Nitrogen also plays a vital role in the plant biochemistry as an essential constituent of cell wall, cytoplasmic proteins, nucleic acid, chlorophyll and other parts of the cell (Hay and Walker, 1989).

\footnotetext{
*Corresponding author: Tel. : +201281594654

E-mail address: sayed_aboelkhair@yahoo.com
}

In this regard, Sadek (2000) showed that increasing the applied $\mathrm{N}$-rates to sweet potato plants from 20 to $80 \mathrm{~kg} /$ fad., recorded significant increases in total and marketable yield, as well as yield/ plant (weight and number). Application of $\mathrm{N}$ up to $50 \mathrm{~kg} / \mathrm{ha}$ increased root yield of sweet potato, but at the highest $\mathrm{N}$ level $(100 \mathrm{~kg} / \mathrm{ha})$ uncontrolled vine growth resulted in lowering root yields (Hartmink et al., 2001). Under sandy soil conditions, Al-Easily (2002) indicated that increasing $\mathrm{N}$ up to $90 \mathrm{~kg} / \mathrm{fad}$., enhanced vine length, number of branches/ plant, leaf area and dry weight of vines, leaves and whole plant. Moreover, nitrogen application at a rate of 60 $\mathrm{kg} /$ fad., gave the highest storage roots dry weight. Farzana et al. (2007) reported that shoot dry weight, storage root dry weight, storage root weight and total yield /ha, N, P, K, Ca and Mg 
contents in shoots or storage roots of sweet potato were significantly increased with application of nitrogen at $30 \mathrm{~kg} / \mathrm{ha}$., comparing with 0 or $100 \mathrm{~kg} \mathrm{~N} / \mathrm{ha}$. Okpara et al. (2009) found that nitrogen application up to $120 \mathrm{~kg}$ $\mathrm{N} / \mathrm{ha}$., increased leaf area index and shoot dry matter, while the storage root yield was increased with increasing $\mathrm{N}$ application up to 80 $\mathrm{kg} \mathrm{N} / \mathrm{ha}$. Garo et al. (2014) reported that $46 \mathrm{~kg}$ $\mathrm{N} / \mathrm{ha}$., produced the longest vine length, maximum top weight and the highest percentage of dry top weight, storage root diameter, root yield and marketable yield than $23 \mathrm{~kg} \mathrm{~N} / \mathrm{ha}$., while the lowest yield and its components were recorded by control treatment (0 nitrogen). Saraswati and Suparno (2015) indicated that $100 \mathrm{~kg} \mathrm{~N} / \mathrm{ha}$., produced the highest tuber yields, while $200 \mathrm{~kg}$ $\mathrm{N} / \mathrm{ha}$., produced greater leaf area of sweet potato.

Whey or a liquid remaining from cheese or casein production is one of the most valuable protein sources in human food chain. In spite of its balanced nutrients, liquid whey is disposed as a waste product. Liquid whey has a high biological oxygen demand, so its disposal in rivers kills living organisms. Environmental pollution is also a concern in many countries (Thivend, 1977). The biological components of whey proteins, including $\beta$-lactoglobulin, $\alpha$-lactalbumin, lactoferrin, lactoperoxidase, immunoglobulins and glycomacropeptides, demonstrate a wide range of immune enhancing properties, and act as antioxidant, antihypertensive, antitumer, antiviral, antimicrobial and chelating agent. They also improve muscle strength and body composition and prevent cardiovascular, cancer diseases and osteoporosis (Marshall, 2004).

Peptides with antioxidative activity can be used as natural antioxidants and can thus replace synthetic antioxidants which have been found to be carcinogenic. Bioactive peptides are inactive within the protein structure, from which they can be released by different methods (Korhonen and Pihlanto, 2006). Several commercial enzymes have been used to obtain bioactive peptides with antioxidants activity from milk proteins, for example by use of the digestive enzymes pepsin, trypsin, and chymotrypsin (De Gobba et al., 2014). In the present study, hydrolysis of goat whey protein with trypsin was monitored for $240 \mathrm{~min}$. Hydrolysates obtained after 60, 120, 180 and $240 \mathrm{~min}$. had DH values of $14 \%, 18 \%, 26 \%$ and $30 \%$, respectively. The antioxidant activity of hydrolysate samples were evaluated by ABTS radical scavenging activity. Hydrolysis of goat whey by trypsin significantly $(\mathrm{P}<0.05)$ increased the antioxidant activity ( $\sim 55 \%$ more activity than un-hydrolyzed goat whey) (data not shown).

In this connection, Abdelbacki et al. (2010) found that when plant was sprayed using $20 \mathrm{ml}$ of the native and chemically modified whey proteins fraction at concentration of $1 \mathrm{mg} / \mathrm{ml}$. shows that whey protein inhibits the virus replication completely in infected plants either the native or the modified form even after seven days from spraying and then increased total yield of tomato.

Erman et al. (2011) showed that the greatest yield, nitrogen and phosphorus content in seeds and shoots were obtained with the treated chickpea plants with whey protein mycorrhizal and Rhizobium alone or in combination than untreated plants.

Therefore, the aim of this work was to minimize using of nitrogen fertilizer by whey protein hydrolysates application to obtain a high tuber root yield with good quality as well as enhancing storability of sweet potato grown in sandy soil.

\section{MATERIALS AND METHODS}

\section{Field Experimental Design}

This research was carried out during the two successive summer seasons of 2013 and 2014 at a Private Vegetable Farm in El-Khattara Distract, Sharkia Governorate, Egypt, to study the effect of different nitrogen rates and whey protein hydrolysates concentrations as foliar application on growth, enzymes, antioxidants, yield, tuber root quality and storability of sweet potato cv. Buregard under sandy soil conditions using drip irrigation system.

The physical and chemical properties of experimental soil in the two seasons showed that it was sandy in texture and had 0.08 and $0.09 \%$ organic matter, 8.13 and $8.07 \mathrm{pH}, 1.82$ and 1.85 mmhos/cm EC, 4.75 and 4.78 ppm available N, 
3.42 and 3.58 ppm available $\mathrm{P}$ and 9.57 and 9.52 ppm available K, respectively.

This experiment included 12 treatments, which were the combinations between three rates of mineral nitrogen (40,60 and $80 \mathrm{~kg} \mathrm{~N} /$ fad.) and three concentrations of whey protein hydrolysates $(0.05,0.10$ and $0.15 \%$ as well as control treatment (tap water). These treatments were arranged in a split plot design in a randomized complete block design with three replications. Nitrogen rates were randomly distributed in the main plots, while the concentration of whey protein were randomly arranged in the sub- plots.

Stem cuttings of sweet potato (about $20 \mathrm{~cm}$ length) were dipped in $0.2 \%$ Rhizolex solution as fungicide for 20 minutes before transplanting and transplanted at $25 \mathrm{~cm}$ apart on April $20^{\text {th }}$ and $24^{\text {th }}$ in the $1^{\text {st }}$ and $2^{\text {nd }}$ seasons, respectively and Buregard cultivar was used in this experiment.

The experimental unit area was $12.6 \mathrm{~m}^{2}$. It contains three dripper lines with $6 \mathrm{~m}$ length each and $70 \mathrm{~cm}$ distance between each two dripper lines. One line was used for taking the samples to measure the morphological and chemical traits and the other two lines were used for yield determinations.

Nitrogen rates were applied with irrigation water (fertigation) weekly into six equal portions beginning 25 days after transplanting in the form of ammonium sulphate $(20.5 \% \mathrm{~N})$.

Plants were sprayed with the different concentrations of whey protein or tap water four times at 15 days intervals beginning 25 days after transplanting in both seasons. Each plot received $2 \mathrm{l}$. solutions of each concentrations using spreading agent in all treatments to improve adherence of the spray to the plant foliage for increasing whey protein absorption by the plants. The untreated plants (check) were sprayed with tap water and spreading agent. One dripper line was left between each two experimental plots without spraying as a guard row to avoid the overlapping of spraying salutation.

All treatments received equal amounts of calcium superphosphate $\left(\begin{array}{lll}15.5 \% & \mathrm{P}_{2} \mathrm{O}_{5}\end{array}\right)$ and potassium sulphate $\left(48.5 \% \mathrm{~K}_{2} \mathrm{O}\right)$ at a rate of 150 and $120 \mathrm{~kg} /$ fad., respectively. One third of
$\mathrm{K}_{2} \mathrm{O}$ amount and all amount of $\mathrm{P}_{2} \mathrm{O}_{5}$ were added during soil preparation with FYM which was added at the rate of $20 \mathrm{~m}^{3} / \mathrm{fad}$. The rest of $\mathrm{K}_{2} \mathrm{O}$ was added into four portions with irrigation water (as fertigation) at 15 days intervals beginning one month after planting. The other conventional practices were applied.

\section{Preparation of Whey Hydrolysate}

Goat milk was obtained from Food Science Department, Faculty of Agriculture, Zagazig University, Egypt. Sweet whey was prepared from goat milk by rennet coagulation according to Ha et al. (2014). The resultant sweet whey was pasteurized at $73^{\circ} \mathrm{C} / 15 \mathrm{~s}$, cooled, lyophilized and freeze at $-20^{\circ} \mathrm{C}$ until use. Lyophilized goat whey (11\% protein) was dissolved in distilled water $(100 \mathrm{~g} / \mathrm{l})$ and hydrolyzed by treatment with Trypsin from porcine pancreas EC 3.4.21.4) from Sigma Chemical Company, St. Louis, MO, USA (E/S ratio of $1: 300(W / W)$ at $37^{\circ} \mathrm{C}$ and $\mathrm{pH} 8$. The hydrolysis was allowed to proceed for 4 hrs., the $\mathrm{pH}$ was kept at 8 during hydrolysis by addition of $1 \mathrm{M} \mathrm{NaOH}$ and the degree of hydrolysis (DH) was determined every $1 \mathrm{hr}$., during hydrolysis according to Adler-Nissen, (1986). At the end of hydrolysis, the enzyme was inactivated by heating at $80^{\circ} \mathrm{C}$ for $20 \mathrm{~min}$. Hydrolysate was clarified by centrifugation at $4000 \mathrm{~g}$ for $30 \mathrm{~min}$ at $16^{\circ} \mathrm{C}$ to remove insoluble substrate fragments, and the supernatant was lyophilized and freeze at $-20^{\circ} \mathrm{C}$ until further use. The antioxidant activity of hydrolysate was evaluated by their ability to scavenge ABTS radicals according to the method described by De Gobba et al. (2014).

\section{Data Recorded \\ Plant Growth}

A random sample of three plants from every experimental unit were randomly taken at 110 days after transplanting in the two growing seasons to measure the plant growth and plant chemical constituents as follows:

a. Vine length $(\mathrm{cm})$ and number of branches/ plant,

b. Leaf area/plant: It was calculated according to the formula described by Koller (1972), and

c. Dry weight of shoots: Leaves and branches of each plant were dried at $70^{\circ} \mathrm{C}$ till constant weight and then weighed. 


\section{Plant Chemical Constituents}

\section{Photosynthetic pigments}

Total chlorophyll was determined in the fourth leaf according to the method described by Wettestein (1957).

\section{Uptake of $N, P$ and $K$ in shoots}

Nitrogen, phosphorus and potassium percentages in shoots (leaves and branches) were determined in dry matter according to the methods described by AOAC (1995) and N,P and $\mathrm{K}$ uptake by shoots were calculated (mg/ shoot).

\section{Antioxidant determination}

Total antioxidants concentration in shoots in response to the treatment was determined by the method of Gupta et al. (2004) with slight modifications by El-Sayed et al. (2012). Briefly, $1 \mathrm{~g}$ of plant leaves was homogenized in mortar containing $20 \mathrm{ml}$ protein extraction buffer (50mM Tris-HCl pH 7.5, 20 mM EDTA) with $0.5 \mathrm{~g}$ sterile sea sand. After $10 \mathrm{~min}$. of homogenization in ice bath, the mixtures were filtered, then the filtrate was centrifuged at 5000 for $10 \mathrm{~min}$. The supernatant was used as the source of antioxidants and intracellular compounds. For antioxidant concentration, $0.5 \mathrm{ml}$ of the plant extract was mixed with $100 \mu \mathrm{l}$ of $20 \mathrm{mM}$ ferrous chloride and $100 \mu \mathrm{l}$ of $30 \%$ ammonium thiocyanate. The developed red complex was measured at $500 \mathrm{~nm}$.

Peroxidase activity was estimated as described by Sarvesh and Reddy (1988). Glutathione oxidase activity was determined according to Bergmeyer et al. (1974) with minor modifications. The reaction contains $200 \mu \mathrm{l}$ of enzyme preparation with $0.1 \mathrm{M}$ glutathione in potassium phosphate buffer $(\mathrm{pH}$ 8.0), $0.2 \mathrm{mM}$ guaiacol and $2 \mathrm{U}$ horseradish peroxidase. After $30 \mathrm{~min}$ incubation at $30^{\circ} \mathrm{C}$, the reaction was stopped by freezing for $15 \mathrm{~min}$, then the developed color was measured at $436 \mathrm{~nm}$. Glutathione oxidase activity was calculated from the following formula:

One unit = A 436/min x 4/ 25.5 (Extinction co-efficient of tetra-guaiacol)

\section{Yield and Its Components}

At harvest time, (at 150 days from transplanting), all tuber roots of each treatment were classified into two grades (marketable and non-marketable roots), then weighed to determine the total yield per faddan (ton). Marketable tuber roots have a weight about 100 to $250 \mathrm{~g}$, while non-marketable roots have a weight of less than $100 \mathrm{~g}$ or more than $250 \mathrm{~g}$. In addition, average tuber root weight was calculated.

\section{Tuber Root Quality at Harvest Time}

\section{Starch content (\%)}

It was determined in dried tuber roots according to the method described by AOAC (1995).

\section{Total sugars (\%)}

It was determined according to the method described by Forsee (1938).

\section{Total soluble solids (TSS\%)}

It was determined in flesh juice of tuber roots by Carle Zeis refractometer.

\section{Caroten content}

It was determined in fresh tuber root tissues according to the method reported by AOAC (1995).

\section{Storability}

At harvest time, the tuber roots from every experimental unit were translocated to a shady place in the same day for curing, and placed for one week. Samples of uniform cured tuber roots $(5 \mathrm{~kg})$ from every experimental unit were put in palm crates and stored at normal room temperature. The storage zero time was on September $28^{\text {th }}$, while the end time of storage was on January $28^{\text {th, }}$ (120 days) in both seasons. The following data were monthly recorded in both seasons:

\section{Weight loss (\%)}

Tuber roots of each treatment were weighed at 30 days by intervals, then the cumulative weight loss percentage was calculated, and

\section{Decay (\%)}

Decayed tuber roots were removed and weighed. They included all spoiled tuber roots resulting from fungal or bacterial infections. The percentage of decayed tuber roots was calculated in relation to the total initial weight of stored tuber roots. 


\section{Statistical Analysis}

Recorded data were subjected to the statistical analysis of variance according to Snedecor and Cochran (1980), and means separation were done according to LSD at 5\% level.

\section{RESULTS AND DISCUSSION}

\section{Plant Growth}

\section{Effect of nitrogen rates}

Data presented in Table 1 show that, fertilizing sweet potato plants grown in sandy soil with nitrogen fertilizer at different rates (40, 60 and $80 \mathrm{~kg} \mathrm{N/fad.)} \mathrm{affected} \mathrm{significantly}$ the vine length, number of branches/ plant, shoots dry weight in both seasons and leaf area in the $1^{\text {st }}$ season. Increasing nitrogen levels up to $80 \mathrm{~kg} \mathrm{~N} /$ fad., increased significantly vine length in both seasons and leaf area in the $1^{\text {st }}$ season. Number of branches and dry weight of shoots/ plant were at the highest values under $60 \mathrm{~kg}$ $\mathrm{N} /$ fad., in both seasons. It is seen also, from the same data, that all the plant vegetative growth characters of sweet potato were at the lowest values under $40 \mathrm{~kg} \mathrm{~N} /$ fad., in both seasons.

The observed increment in above ground biomass of sweet potato due to nitrogen fertilization may be attributed to the high levels of nitrogen stimulated the development of adventitious buds and shoots. Accordingly, the growth of vine length, branch number and leaf per plant contributed for the increment of above ground biomass (Garo et al., 2014). These results are in agreement with those obtained by Al-Easily (2002), Farzana et al. (2007) and Saraswati and Suparno (2015).

\section{Effect of WPH}

The same data in the same table show that, spraying sweet potato plants grown in sandy soil with $0.15 \%$ WPH (antioxidants agent) increased vine length, leaf area/plant, number of branches/ plant and dry weight of shoots/ plant in both seasons, without significant differences with WPH at $0.10 \%$ regarding number of branches/ plant in the $1^{\text {st }}$ season and leaf area/ plant in both seasons. On the other hand, the lowest values of all vegetative growth characters of sweet potato were obtained by spraying plants with tap water in both seasons. These results are in conformation with that of Thomson et al. (2015).

\section{Effect of interaction between nitrogen and WPH}

Data in the Table 1 indicate that, the interaction between $60 \mathrm{~kg} \mathrm{~N} / \mathrm{fad}$., and spraying plants with $0.15 \%$ WPH increased significantly number of branches/plant, leaf area/ plant and shoots dry weight/plant in both seasons, without significant differences with the interaction between $60 \mathrm{~kg} \mathrm{~N} / \mathrm{fad}$., and spraying with $0.10 \%$ WPH in few cases. Whereas, the interaction between $80 \mathrm{~kg} \mathrm{~N} / \mathrm{fad}$., and spraying with $0.15 \%$ WPH increased significantly vine length in both seasons.

\section{Total Chlorophyll and N, P and K Uptake}

\section{Effect of nitrogen rates}

Data presented in Table 2 show that the highest concentration of total chlorophyll in leaf tissues were obtained with $80 \mathrm{~kg} \mathrm{~N} / \mathrm{fad}$., without significant differences with $60 \mathrm{~kg} \mathrm{~N} /$ fad., in both seasons.

It is evident from the data illustrated in Table 2 that nitrogen rates reflected significant effect on $\mathrm{N}, \mathrm{P}$ and $\mathrm{K}$ uptakes/shoot in both seasons. The medium level of nitrogen (60 kg N/fad.) showed enhancing effect on minerals uptake by shoots in both season, without significant differences with $80 \mathrm{~kg} \mathrm{~N} / \mathrm{fad}$., with respect to $\mathrm{N}$ uptake in the $1^{\text {st }}$ season, $\mathrm{P}$ uptake in both seasons, and $\mathrm{K}$ uptake in the $1^{\text {st }}$ season, while $\mathrm{N}, \mathrm{P}$ and $\mathrm{K}$ uptake were at minimum values under low level (40 kg N/fad.). Nitrogen plays a vital role in the plant biochemistry as an essential constituent of cell wall, cytoplasmic proteins, nucleic acid, chlorophyll and other parts of the cell (Hay and Walker, 1989). Similar results were obtained by Phillips and Warren (2005) and Farzana et al. (2007) on sweet potato.

\section{Effect of WPH}

Data in Table 2 reveal that whey protein had significant effect on total chlorophyll in leaf tissues and NPK uptake/shoot in both seasons. It is quite clear that total chlorophyll, $\mathrm{N}, \mathrm{P}$ and $\mathrm{K}$ uptake by shoots were at maximum values by spraying plants with $0.15 \%$ WPH without significant differences with $0.10 \%$ WPH with respect to total chlorophyll in leaf tissues in the $1^{\text {st }}$ season and $\mathrm{P}$ uptake by shoot in both seasons. 
Table 1. Effect of nitrogen rates, whey protein and their interactions on growth characters of sweet potato during 2013 and 2014 seasons

\begin{tabular}{|c|c|c|c|c|c|c|c|c|c|}
\hline \multirow{2}{*}{\multicolumn{2}{|c|}{ Treatments }} & \multicolumn{2}{|c|}{$\begin{array}{c}\text { Vine length } \\
(\mathrm{cm})\end{array}$} & \multicolumn{2}{|c|}{$\begin{array}{c}\text { Number of branches/ } \\
\text { plant }\end{array}$} & \multicolumn{2}{|c|}{$\begin{array}{c}\text { Leaf area/ plant } \\
\left(\mathrm{m}^{2}\right)\end{array}$} & \multicolumn{2}{|c|}{$\begin{array}{c}\begin{array}{c}\text { Dry weight of shoots } \\
\text { (g/plant) }\end{array} \\
\end{array}$} \\
\hline & & $\begin{array}{c}2013 \\
\text { season }\end{array}$ & $\begin{array}{c}2014 \\
\text { season }\end{array}$ & $\begin{array}{c}2013 \\
\text { season }\end{array}$ & $\begin{array}{c}2014 \\
\text { season }\end{array}$ & $\begin{array}{c}2013 \\
\text { season }\end{array}$ & $\begin{array}{c}2014 \\
\text { season }\end{array}$ & $\begin{array}{c}2013 \\
\text { season }\end{array}$ & $\begin{array}{c}2014 \\
\text { season }\end{array}$ \\
\hline \multicolumn{2}{|l|}{ Nitrogen rates } & \multicolumn{8}{|c|}{ Effect of nitrogen rates (kg N/fad.) } \\
\hline \multicolumn{2}{|l|}{$40 \mathrm{~kg} /$ fad. } & 106.82 & 109.67 & 10.94 & 10.39 & 0.63 & 0.72 & 59.07 & 56.09 \\
\hline \multicolumn{2}{|l|}{$60 \mathrm{~kg} / \mathrm{fad}}$. & 111.10 & 111.15 & 13.99 & 13.26 & 0.70 & 0.76 & 71.89 & 67.98 \\
\hline \multicolumn{2}{|l|}{80 kg/fad. } & 119.20 & 118.17 & 13.62 & 12.12 & 0.74 & 0.76 & 70.06 & 66.35 \\
\hline \multicolumn{2}{|l|}{ LSD at $5 \%$ level } & 2.27 & 1.32 & 1.62 & 1.47 & 0.06 & NS & 0.98 & 1.29 \\
\hline \multicolumn{2}{|c|}{ Whey protein (\%) } & \multicolumn{8}{|c|}{ Effect of whey protein rates (\%) } \\
\hline \multicolumn{2}{|l|}{0.0} & 105.23 & 115.83 & 9.40 & 9.17 & 0.57 & 0.62 & 50.52 & 50.65 \\
\hline \multicolumn{2}{|l|}{$0.05(\%)$} & 112.23 & 111.96 & 12.57 & 11.90 & 0.66 & 0.72 & 66.33 & 59.02 \\
\hline \multicolumn{2}{|l|}{$0.10(\%)$} & 114.93 & 115.67 & 14.21 & 12.92 & 0.75 & 0.80 & 74.19 & 70.17 \\
\hline \multicolumn{2}{|l|}{$0.15(\%)$} & 117.10 & 119.13 & 15.21 & 13.71 & 0.78 & 0.84 & 76.99 & 74.05 \\
\hline \multicolumn{2}{|c|}{ LSD at $5 \%$ level } & 1.99 & 2.85 & 1.56 & 0.42 & 0.05 & 0.09 & 0.86 & 1.13 \\
\hline Nitrogen rates & Whey protein & \multicolumn{8}{|c|}{ Effect of interaction treatments } \\
\hline \multirow[t]{3}{*}{$40 \mathrm{~kg} / \mathrm{fad}$} & 0.0 & 102.80 & 101.60 & 7.73 & 7.50 & 0.56 & 0.59 & 46.82 & 48.29 \\
\hline & $0.10(\%)$ & 10.860 & 113.10 & 11.96 & 11.20 & 0.66 & 0.77 & 63.47 & 58.06 \\
\hline & $0.15(\%)$ & 108.50 & 113.10 & 13.10 & 11.97 & 0.68 & 0.81 & 65.77 & 63.40 \\
\hline \multirow[t]{4}{*}{60 kg /fad. } & 0.0 & 106.10 & 108.50 & 10.08 & 10.18 & 0.57 & 0.63 & 53.48 & 51.62 \\
\hline & $0.05(\%)$ & 110.90 & 108.70 & 11.92 & 11.06 & 0.61 & 0.70 & 61.22 & 55.63 \\
\hline & $0.10(\%)$ & 112.10 & 111.00 & 16.63 & 15.60 & 0.75 & 0.80 & 81.21 & 80.12 \\
\hline & $0.15(\%)$ & 115.30 & 116.40 & 17.33 & 16.23 & 0.90 & 0.92 & 91.66 & 84.58 \\
\hline \multirow[t]{4}{*}{80 kg /fad. } & 0.0 & 106.80 & 107.40 & 10.40 & 9.84 & 0.58 & 0.64 & 51.26 & 52.06 \\
\hline & $0.05(\%)$ & 118.40 & 116.30 & 14.82 & 13.76 & 0.76 & 0.7 & 77.56 & 66.81 \\
\hline & $0.10(\%)$ & 124.60 & 121.10 & 14.04 & 11.96 & 0.85 & 0.84 & 77.90 & 72.34 \\
\hline & $0.15(\%)$ & 127.50 & 127.90 & 15.22 & 12.95 & 0.77 & 0.80 & 73.54 & 74.19 \\
\hline \multicolumn{2}{|c|}{ LSD at $5 \%$ level } & 3.45 & 4.93 & 2.74 & 0.74 & 0.09 & 0.15 & 1.49 & 1.96 \\
\hline
\end{tabular}


Table 2. Effect of nitrogen rates, whey protein and their interactions on total chlorophyll in leaf tissues, N, P and K uptake (mg) by shoots of sweet potato during 2013 and 2014 seasons

\begin{tabular}{|c|c|c|c|c|c|c|c|c|c|}
\hline \multirow{2}{*}{\multicolumn{2}{|c|}{ Treatments }} & \multicolumn{2}{|c|}{$\begin{array}{c}\text { Total chlorophyll } \\
\text { ( mg/g DW) }\end{array}$} & \multicolumn{2}{|c|}{$\mathbf{N}$} & \multicolumn{2}{|c|}{$\mathbf{P}$} & \multicolumn{2}{|c|}{$\overline{\mathbf{K}}$} \\
\hline & & $\begin{array}{c}2013 \\
\text { season }\end{array}$ & $\begin{array}{c}2014 \\
\text { season }\end{array}$ & $\begin{array}{c}2013 \\
\text { season }\end{array}$ & $\begin{array}{c}2014 \\
\text { season }\end{array}$ & $\begin{array}{c}2013 \\
\text { season }\end{array}$ & $\begin{array}{c}2014 \\
\text { season }\end{array}$ & $\begin{array}{c}2013 \\
\text { season }\end{array}$ & $\begin{array}{r}2014 \\
\text { season }\end{array}$ \\
\hline \multicolumn{2}{|l|}{ Nitrogen rates } & \multicolumn{8}{|c|}{ Effect of nitrogen rates (kg N/fad.) } \\
\hline \multicolumn{2}{|c|}{$40 \mathrm{~kg} / \mathrm{fad}}$. & 3.98 & 4.02 & 1571 & 1420 & 315 & 303 & 1124 & 1108 \\
\hline \multicolumn{2}{|c|}{$80 \mathrm{~kg} / \mathrm{fad}$. } & 4.85 & 4.84 & 1952 & 1664 & 356 & 349 & 1531 & 1550 \\
\hline \multicolumn{2}{|c|}{ LSD at $5 \%$ level } & 0.36 & 0.45 & 187 & 135 & 36 & 30 & 109 & 118 \\
\hline \multicolumn{2}{|c|}{ Whey protein (\%) } & \multicolumn{8}{|c|}{ Effect of whey protein rates (\%) } \\
\hline \multicolumn{2}{|l|}{$\mathbf{0 . 0}$} & 3.78 & 3.71 & 1168 & 1127 & 249 & 256 & 866 & 882 \\
\hline \multicolumn{2}{|l|}{$0.05(\%)$} & 4.41 & 4.21 & 1772 & 1451 & 328 & 296 & 1257 & 1204 \\
\hline \multicolumn{2}{|l|}{$0.10(\%)$} & 4.75 & 4.81 & 2140 & 1886 & 374 & 382 & 1562 & 1507 \\
\hline \multicolumn{2}{|l|}{$0.15(\%)$} & 4.85 & 4.98 & 2350 & 2089 & 372 & 375 & 1782 & 1793 \\
\hline Nitrogen rates & Whey protein & \multicolumn{8}{|c|}{ Effect of interaction treatments } \\
\hline \multirow[t]{4}{*}{40 kg /fad. } & 0.0 & 3.58 & 3.48 & 936 & 1067 & 234 & 246 & 725 & 738 \\
\hline & $0.05(\%)$ & 4.05 & 3.80 & 1565 & 1343 & 319 & 289 & 1084 & 1037 \\
\hline & $0.10(\%)$ & 4.09 & 4.26 & 1808 & 1532 & 352 & 325 & 1282 & 1219 \\
\hline & $0.15(\%)$ & 4.19 & 4.52 & 1973 & 1737 & 355 & 355 & 1407 & 1439 \\
\hline \multirow[t]{4}{*}{$60 \mathrm{~kg} / \mathrm{fad}}$. & 0.0 & 3.88 & 3.81 & 1369 & 1275 & 262 & 258 & 962 & 949 \\
\hline & $0.05(\%)$ & 4.23 & 3.81 & 1640 & 1446 & 287 & 267 & 1089 & 973 \\
\hline & $0.10(\%)$ & 4.94 & 5.06 & 2347 & 2203 & 373 & 432 & 1583 & 1538 \\
\hline & $0.15(\%)$ & 4.97 & 5.07 & 2841 & 2402 & 366 & 363 & 2144 & 2063 \\
\hline \multirow[t]{4}{*}{$80 \mathrm{~kg} / \mathrm{fad}}$. & 0.0 & 3.87 & 3.84 & 1199 & 1041 & 251 & 265 & 912 & 957 \\
\hline & $0.05(\%)$ & 4.94 & 5.03 & 2109 & 1563 & 380 & 334 & 1597 & 1603 \\
\hline & $0.10(\%)$ & 5.22 & 5.12 & 2266 & 1924 & 397 & 390 & 1822 & 1765 \\
\hline & $0.15(\%)$ & 5.38 & 5.36 & 2235 & 2129 & 397 & 408 & 1794 & 1877 \\
\hline \multicolumn{2}{|c|}{ LSD at $5 \%$ level } & 0.24 & 0.24 & 185 & 175 & 55 & 50 & 145 & 197 \\
\hline
\end{tabular}


These results are in harmony with those obtained by Erman et al. (2011). They showed that the nitrogen and phosphorus content in shoots were obtained with by treating chickpea plants with whey protein, mycorrhizal and Rhizobium alone or in combination than untreated plants .

\section{Effect of interaction between nitrogen rates and WPH}

The results in Table 2 indicate that the uppermost values of total chlorophylls in leaf tissues were obtained with the interaction between $80 \mathrm{~kg} \mathrm{~N} / \mathrm{fad}$., and spraying with 0.10 or $0.15 \%$ whey protein, while the lowermost values were obtained with $40 \mathrm{~kg} \mathrm{~N} /$ fad., and spraying with tap water in both seasons.

Concerning N, P and K uptake by shoots, the interaction between $60 \mathrm{~kg} \mathrm{~N} / \mathrm{fad}$., and spraying plants with $0.15 \%$ whey protein recorded the maximum values of $\mathrm{N}$ and $\mathrm{K}$ uptakes by shoots. Whereas, the maximum values of $\mathrm{P}$ uptake was obtained by the interaction between $80 \mathrm{~kg} \mathrm{~N} /$ fad., and spraying plants with $0.10 \%$ whey protein in the $1^{\text {st }}$ season and with the interaction between $60 \mathrm{~kg} \mathrm{~N} / \mathrm{fad}$., and spraying plants with $0.10 \%$ whey protein in the $2^{\text {nd }}$ season (Table 2 ).

\section{Enzymes and Antioxidants Activity}

\section{Effect of nitrogen rates}

Data in Table 3 show that nitrogen rates reflected a significant effect on enzymes and antioxidant concentrations in sweet potato shoots. It is obvious that glutathione oxidase and peroxidase enzymes as well as antioxidants increased with increasing nitrogen rates up to 80 $\mathrm{kg} \mathrm{N} / \mathrm{fad}$., with no significant differences with $40 \mathrm{~kg} \mathrm{~N} / \mathrm{fad}$., with respect to glutathione oxidase. These results suggested that exposing sweet potato plants to the highest level of nitrogen increased peroxidase enzyme and antioxidants and vice versa in both seasons.

\section{Effect of WPH}

The obtained results in Table 3 show that WPH treatments revealed quite comparable effects in both seasons on glutathione oxidase, peroxidase enzymes and antioxidants. Moreover, applying $0.15 \%$ WPH led to significantly increment in glutathione oxidase, peroxidase and antioxidants concentration in shoots when compared with other whey protein treatments. In addition, plants sprayed with tap water (control) recorded the lowest values of enzymes and antioxidants.

The biological components of whey proteins, including $\quad \beta$-lactoglobulin, $\alpha$-lactalbumin, lactoferrin, lactoperoxidase, immunoglobulins and glycomacropeptides, demonstrate a wide range of immune enhancing properties, and act as antioxidant, antihypertensive, antitumer, antiviral, antimicrobial and chelating agent (Marshall, 2004).

The antioxidant activity of hydrolysate samples were evaluated by ABTS radical scavenging activity. Hydrolysis of goat whey by trypsin significantly $(\mathrm{P}<0.05)$ increased the antioxidant activity ( $\sim 5 \%$ more activity than un-hydrolyzed goat whey) (data not shown).

Mehrabian et al. (2011) recorded that salicylic acid (SA) is a phenolic compound with antioxidant properties, and involved in the regulation of physiological processes in plants. SA effects on catalase and peroxidase enzymes. The plants treated with salicylic acid increased the activity of enzymes such as catalase, peroxidase, superoxide dismutase, ascorbate peroxidase, glutathione reductase, etc. (Manochehrifar, 2010).

\section{Effect of interaction between nitrogen rates and WPH}

Data in Table 3 show that 40 or $80 \mathrm{~kg} \mathrm{~N} / \mathrm{fad}$., interacted with any rates of whey protein recorded the best results for glutathione oxidase enzyme comparing with $60 \mathrm{~kg} \mathrm{~N} / \mathrm{fad}$., under any rate of WPH in both seasons. Concerning, peroxidase enzyme and antioxidants in shoots, the same data in the Table 3 show that, the interaction between $80 \mathrm{~kg} \mathrm{~N} /$ fad., and spraying with $0.15 \%$ WPH recorded the highest concentration of peroxidase enzyme and antioxidants in shoot of sweet potato in both seasons. As for glutathione oxidase, the highest concentration in shoots of sweet potato was obtained by the interaction between $40 \mathrm{~kg} \mathrm{~N}$ /fad., and $0.15 \%$ WPH in both seasons. On the other hand, the interaction between $40 \mathrm{Kg}$ $\mathrm{N} /$ fad., and untreated plants (check) gave the lowest concentration of peroxidase enzyme and antioxidants in shoots of sweet potato in both seasons. 
Table 3. Effect of nitrogen rates, whey protein and their interactions on enzymes and antioxidants in shoots of sweet potato during 2013 and 2014 seasons

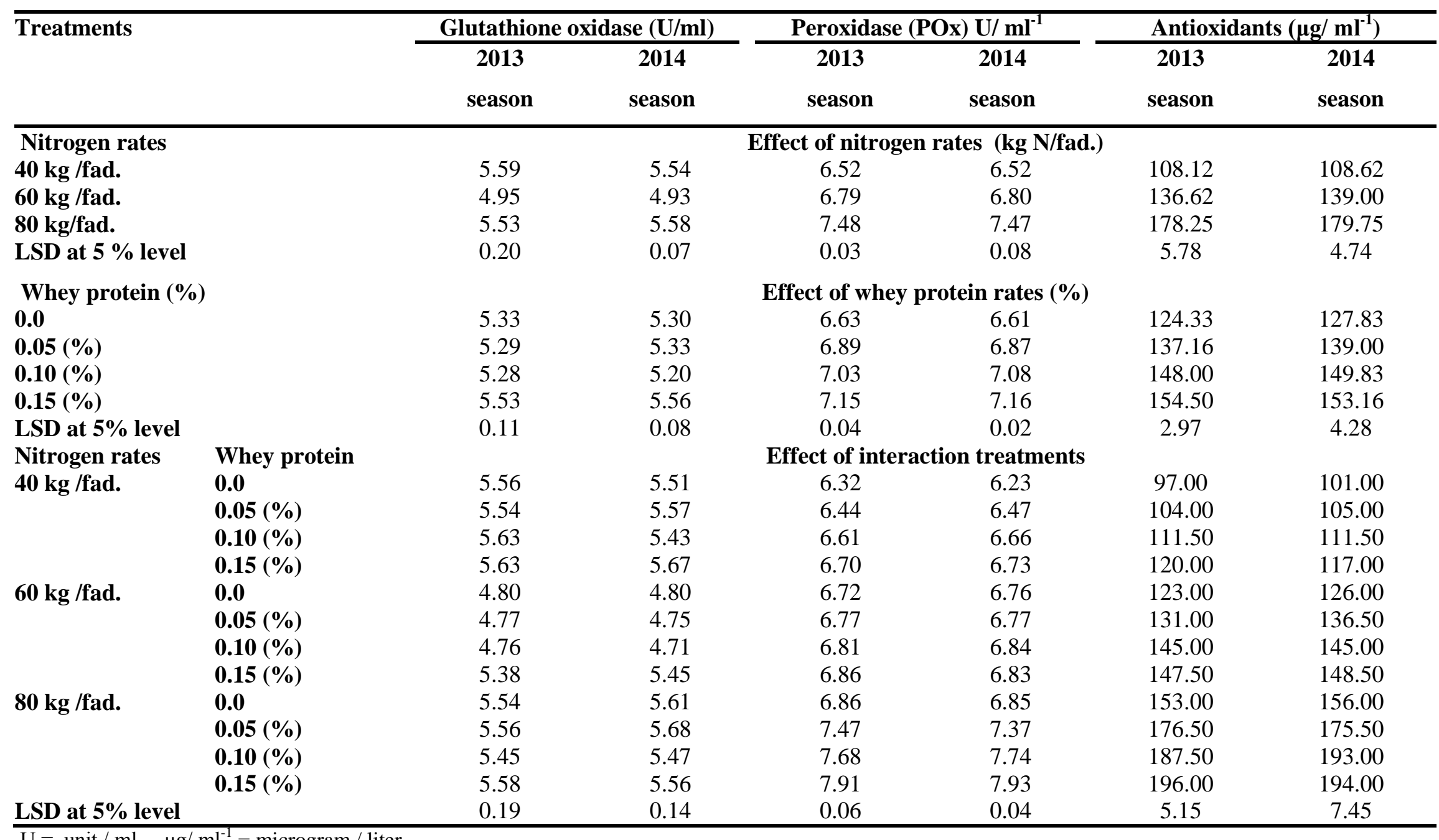




\section{Yield and Its Components}

\section{Effect of nitrogen rates}

It is obvious from the data in Table 4 that average tuber root weight, marketable and total yield/ fad., in both seasons were significantly increased with increasing nitrogen rate up to the medium level (60 kg N/fad.), while unmarketable yield in the $2^{\text {nd }}$ season was significantly decreased.

Increasing the applied nitrogen rate to sweet potato plants up to $60 \mathrm{~kg} \mathrm{~N} /$ fad., increased the total yield by 39.7 and $40.80 \%$ over the plants received $40 \mathrm{~kg} \mathrm{~N} /$ fad., in the $1^{\text {st }}$ and $2^{\text {nd }}$ seasons, respectively and 23.60 and $25.80 \%$ over the plants received $80 \mathrm{~kg} \mathrm{~N} / \mathrm{fad}$., in the $1^{\text {st }}$ and $2^{\text {nd }}$ seasons, respectively. The increase in total tuber yield was clearly achieved owing to the increases in average tuber weight. In addition, the obtained results with yield and its components reflected similar trend to that obtained with plant growth.

Since nitrogen stimulates branch development and leaf production which indirectly contribute for root yield. In addition, the availed nitrogen in the soil is important in tuber initiation and tuber enlargement (Sikka, 1982).

This result agreed with those reported by Garo et al. (2014) and Saraswati and Suparno (2015) on sweet potato. They found that, the highest yield was increased under the moderate rate of nitrogen.

\section{Effect of WPH}

It is obvious from the data in Table 4 that, spraying sweet potato plants with $0.15 \% \mathrm{WPH}$ led to attain the highest values of tuber weight, marketable and total yield/fad., and reduction of unmarketable yield in both seasons. The total yield/fad., increased by about 20.10 and $12.60 \%$ after spraying with $0.15 \%$ WPH than plants sprayed with tap water in the $1^{\text {st }}$ and $2^{\text {nd }}$ seasons, respectively. These results are in harmony with those reported by Abdelbacki et al. (2010) on tomato and Erman et al. (2011) on chickpea.

In the present study, the WPH recorded antioxidants activity. Increasing the production of green pods and dry seeds of pea with high quality could be achieved through using the foliar application of plant growth substances and antioxidants (Thomson et al., 2015).

\section{Effect of interaction between nitrogen rates and $\mathrm{WPH}$}

The interaction between $60 \mathrm{~kg} \mathrm{~N} / \mathrm{fad}$., and spraying plants with $0.15 \%$ WPH was the most favourable treatment for increasing average weight of tuber roots, marketable yield and total yield compared with all other interaction treatments, whereas the interaction between 60 $\mathrm{kg} \mathrm{N} /$ fad., and $0 \mathrm{WPH}$ increased unmarketable yield. The interaction between $40 \mathrm{~kg} \mathrm{~N} / \mathrm{fad}$., and spraying with distilled water (check) gave the lowermost values of yield and its components (Table 4). In addition, the total yield/fad., increased by about 71.70 and $60.70 \%$ after fertilizing plants with $60 \mathrm{~kg} \mathrm{~N} /$ fad., and spraying plants with $0.15 \%$ WPH than plants received 40 $\mathrm{kg} \mathrm{N} /$ fad., and sprayed with tap water in the $1^{\text {st }}$ and $2^{\text {nd }}$ seasons, respectively.

\section{Tuber Root Quality}

\section{Effect of nitrogen rates}

Data in Table 5 illustrate that TSS, total sugars content in tuber roots were at the highest values under the moderate rate of nitrogen (60 $\mathrm{kg} \mathrm{N} /$ fad.), while carotene and starch contents in tuber roots were at the highest with 40 and $80 \mathrm{~kg} \mathrm{~N} /$ fad., respectively. Excessive amounts of $\mathrm{N}$ may encourage excessive vine growth and result in cracked and poor storage quality (Lerner, 2001).

This result was in agreement with Essilfie (2015) who found that higher beta-carotene content tubers occurred in sweet potato grown under fertilization rate $15 \mathrm{~kg} \mathrm{~N} / \mathrm{ha}$., while higher tuber starch content was recorded from plants grown under fertilization rate $30 \mathrm{~kg} \mathrm{~N} / \mathrm{ha}$.

\section{Effect of WPH}

It is evident that WPH had significant effect on starch, TSS, and total sugars in tuber roots in both seasons. But, they had no significant effect on carotene content in both seasons (Table 5). It is also clear that, $0.15 \% \mathrm{WPH}$ increased starch, TSS, and total sugars contents with no significant differences with $0.10 \% \mathrm{WPH}$.

It could be concluded that $0.10 \%$ WPH increased starch, TSS and total sugars in tuber roots. 
Table 4. Effect of nitrogen rates, whey protein and their interactions on yield and its components of sweet potato during 2013 and 2014 seasons

\begin{tabular}{|c|c|c|c|c|c|c|c|c|c|c|c|}
\hline \multirow[t]{2}{*}{ Treatments } & & \multicolumn{2}{|c|}{$\begin{array}{c}\text { Average weight of } \\
\text { tuber root (g) }\end{array}$} & \multicolumn{2}{|c|}{$\begin{array}{c}\text { Unmarketable yield } \\
\text { (ton/fad.) } \\
\end{array}$} & \multicolumn{2}{|c|}{$\begin{array}{c}\text { Marketable yield } \\
\text { (ton/fad.) }\end{array}$} & \multicolumn{2}{|c|}{$\begin{array}{c}\text { Total yield } \\
\text { (ton/fad.) }\end{array}$} & \multicolumn{2}{|c|}{$\begin{array}{c}\text { Relative increases in } \\
\text { total yield (\%) } \\
\end{array}$} \\
\hline & & $\begin{array}{c}2013 \\
\text { season }\end{array}$ & $\begin{array}{c}2014 \\
\text { season }\end{array}$ & $\begin{array}{c}2013 \\
\text { season }\end{array}$ & $\begin{array}{c}2014 \\
\text { season }\end{array}$ & $\begin{array}{c}2013 \\
\text { season }\end{array}$ & $\begin{array}{c}2014 \\
\text { season }\end{array}$ & $\begin{array}{c}2013 \\
\text { season }\end{array}$ & $\begin{array}{c}2014 \\
\text { season }\end{array}$ & $\begin{array}{c}2013 \\
\text { season }\end{array}$ & $\begin{array}{c}2014 \\
\text { season }\end{array}$ \\
\hline \multicolumn{2}{|c|}{ Nitrogen rates } & \multicolumn{10}{|c|}{ Effect of nitrogen rates (kg N/fad.) } \\
\hline \multicolumn{2}{|l|}{40 kg /fad. } & 136.89 & 146.34 & 2.760 & 3.223 & 7.250 & 6.985 & 10.010 & 10.208 & 100.0 & 100.0 \\
\hline \multicolumn{2}{|l|}{$60 \mathrm{~kg} / \mathrm{fad}}$. & 160.38 & 164.70 & 2.565 & 2.663 & 11.419 & 11.710 & 13.984 & 14.373 & 139.7 & 140.8 \\
\hline \multicolumn{2}{|l|}{80 kg/fad. } & 141.75 & 147.96 & 2.705 & 2.708 & 9.671 & 10.129 & 12.376 & 12.838 & 123.6 & 125.8 \\
\hline \multicolumn{2}{|c|}{ Whey protein (\%) } & \multicolumn{10}{|c|}{ Effect of whey protein rates (\%) } \\
\hline \multicolumn{2}{|l|}{$\mathbf{0 . 0}$} & 124.92 & 129.24 & 3.481 & 3.883 & 7.503 & 7.734 & 10.983 & 11.617 & 100.0 & 100.0 \\
\hline \multicolumn{2}{|l|}{$0.05(\%)$} & 141.12 & 153.00 & 2.796 & 3.461 & 8.898 & 8.977 & 11.694 & 12.438 & 106.5 & 107.1 \\
\hline \multicolumn{2}{|l|}{$0.10(\%)$} & 154.44 & 160.92 & 2.627 & 2.280 & 9.996 & 10.478 & 12.623 & 12.757 & 114.9 & 109.8 \\
\hline \multicolumn{2}{|l|}{$0.15(\%)$} & 164.88 & 168.84 & 1.802 & 1.836 & 11.389 & 11.241 & 13.191 & 13.077 & 120.1 & 112.6 \\
\hline \multicolumn{2}{|c|}{ LSD at $5 \%$ level } & 4.28 & 6.27 & 0.178 & 0.238 & 0.137 & 0.199 & 0.239 & 0.273 & -- & -- \\
\hline \multicolumn{5}{|c|}{ Nitrogen rates Whey protein } & \multicolumn{5}{|c|}{ Effect of interaction treatments } & & \\
\hline \multirow[t]{3}{*}{40 kg /fad. } & $\mathbf{0 . 0}$ & 116.64 & 122.04 & 2.992 & 3.503 & 5.641 & 5.712 & 8.633 & 9.215 & 100.0 & 100.0 \\
\hline & $0.10(\%)$ & 143.64 & 157.68 & 2.956 & 3.589 & 7.599 & 7.212 & 10.555 & 10.801 & 122.3 & 117.2 \\
\hline & $0.15(\%)$ & 152.28 & 156.60 & 2.197 & 2.380 & 9.153 & 8.215 & 11.350 & 10.595 & 131.5 & 115.0 \\
\hline \multirow[t]{4}{*}{60 kg /fad. } & 0.0 & 128.52 & 135.00 & 3.666 & 4.110 & 9.006 & 9.700 & 12.672 & 13.810 & 146.8 & 149.9 \\
\hline & $0.05(\%)$ & 157.68 & 164.16 & 2.279 & 2.842 & 11.838 & 11.347 & 14.117 & 14.189 & 163.5 & 154.0 \\
\hline & $0.10(\%)$ & 169.56 & 172.80 & 2.540 & 2.042 & 11.786 & 12.639 & 14.326 & 14.681 & 165.9 & 159.3 \\
\hline & $0.15(\%)$ & 185.76 & 186.84 & 1.777 & 1.657 & 13.044 & 13153 & 14.821 & 14.810 & 171.7 & 160.7 \\
\hline \multirow[t]{4}{*}{80 kg /fad. } & 0.0 & 129.60 & 130.68 & 3.786 & 4.035 & 7.860 & 7.792 & 11.646 & 11.827 & 134.9 & 128.3 \\
\hline & $0.05(\%)$ & 130.68 & 145.80 & 3.216 & 4.119 & 8.249 & 8.785 & 11.465 & 12.904 & 132.8 & 140.0 \\
\hline & $0.10(\%)$ & 150.12 & 152.28 & 2.385 & 1.208 & 10.604 & 11.583 & 12.989 & 12.791 & 150.5 & 138.8 \\
\hline & $0.15(\%)$ & 156.60 & 163.08 & 1.433 & 1.472 & 11.97 & 12.356 & 13.403 & 13.828 & 155.3 & 150.1 \\
\hline \multicolumn{2}{|c|}{ LSD at $5 \%$ level } & 7.42 & 10.87 & 0.327 & 0.416 & 0.238 & 0.345 & 0.416 & 0.475 & -- & -- \\
\hline
\end{tabular}




\section{Effect of interaction between nitrogen rates and $\mathrm{WPH}$}

Data in Table 5 reveal that the interaction between nitrogen rates and WPH had significant effect on all traits of tuber roots quality. In general, the interaction between $60 \mathrm{~kg} \mathrm{~N} / \mathrm{fad}$. and 0.10 or $0.15 \%$ WPH gave the highest values regarding TSS and total sugars, while carotene content in tuber roots was the highest with the interaction between $40 \mathrm{~kg} \mathrm{~N} / \mathrm{fad}$., and foliar spray with $0.15 \% \mathrm{WPH}$ in both seasons. On the other side, the best result for starch content was obtained by the interaction between $80 \mathrm{~kg} \mathrm{~N} /$ fad., and spraying plants with 0.10 or $0.15 \%$ WPH in both seasons.

It could be concluded that, the interaction between $40 \mathrm{~kg}$ N/fad., and 0.10\% WPH increased carotene content, whereas the interaction between $60 \mathrm{~kg} \mathrm{~N} /$ fad., and $0.10 \% \mathrm{WPH}$ increased TSS and total sugars and the interaction between 80 $\mathrm{kg} \mathrm{N} /$ fad., and $0.10 \% \mathrm{WPH}$ increased starch content.

\section{Storability (Weight Loss and Decay \%)}

\section{Effect of nitrogen rates}

It is evident from data in Tables 6 and 7 that, the obtained values of weight loss and decay (\%) gradually increased by increasing storage period and reached their maximum peak at 120 days after harvest time (the end of storage period) under the conditions of this study.

Furthermore, it is quite clear from the obtained results that the lowest values of all storability parameters (weight loss and decay) of sweet potato tuber roots; i.e., during storage period were more achieved when sweet potato plants received $60 \mathrm{~kg} \mathrm{~N} / \mathrm{fad}$., during the growing season. Moreover, such treatment being the best one for increasing the storability of sweet potato tuber roots.

From the above mentioned results, it could be suggested that sweet potato tuber roots produced from the highest level of nitrogen (80 $\mathrm{kg} \mathrm{N} /$ fad.) were faster in weight loss and decay percentage as compared with the other treatments during storage period (120 days after harvest time).
This result was in agreement with Essilfie (2015), who found that application of moderate level of nitrogen (15 kg /ha.) recorded the lower weight loss (\%) in tuber roots during storage of sweet potato than $30 \mathrm{~kg} \mathrm{~N} / \mathrm{ha}$. Also, Fatideh and Asil (2012) found that the least weight loss percentage was recorded in the bulbs grown under nitrogen fertilization at $100 \mathrm{~kg} / \mathrm{ha}$., than $150 \mathrm{~kg} / \mathrm{ha}$., on onion.

\section{Effect of WPH}

It is obvious from such data that, weight loss and decay (\%), gradually, increased by increasing storage period and recorded the maximum values at 120 days after harvest time (the end of storage period) under the conditions of this study (Tables 6 and 7).

Spraying plants with $0.15 \% \mathrm{WPH}$ being the most effective and favourable treatment for giving the minimum values of weight loss (\%) and decay (\%) in tuber roots during storage period. In other words, such treatment increased the storage period of sweet potato tuber roots, as well as being the superior treatment in this respect as compared with the other treatments.

This result agreed with those reported by AlMughrabi (2007) who showed that the combination between compost tea and WPH reduced disease severity by $21 \%$ in potatoes.

\section{Effect of interaction between nitrogen rates and $\mathrm{WPH}$}

It is quite clear from data presented in Tables 6 and 7 that, the best interaction treatments for decreasing weight loss and decay (\%) were fertilizing sweet potato with $60 \mathrm{~kg} \mathrm{~N} / \mathrm{fad}$., and spraying plants with 0.10 or $0.15 \%$ WPH in both seasons. On the other hand, the highest values of weight loss and decay (\%) were obtained by fertilizing plants with $80 \mathrm{~kg} \mathrm{~N} / \mathrm{fad}$ and spraying plants with $0.0 \% \mathrm{WPH}$ (distilled water).

Finally, it could be concluded that, fertilizing sweet potato plants cv. Buregard grown in sandy soil with $\mathrm{N}$ at $60 \mathrm{~kg} / \mathrm{fad}$., and foliar spray with $0.15 \%$ WPH was the best treatment for enhancing plant growth, improving yield and best quality at harvest as well as storability of tuber roots of sweet potato. 
Table 5. Effect of nitrogen rates, whey protein and their interactions on tuber root quality of sweet potato at harvest time during 2013 and 2014 seasons

\begin{tabular}{|c|c|c|c|c|c|c|c|c|c|}
\hline \multirow{2}{*}{\multicolumn{2}{|c|}{ Treatments }} & \multicolumn{2}{|c|}{ Starch (\%) } & \multicolumn{2}{|c|}{ TSS (\%) } & \multicolumn{2}{|c|}{ Total sugars (\%) } & \multicolumn{2}{|c|}{ Carotene (mg/g FW) } \\
\hline & & $\begin{array}{c}2013 \\
\text { season }\end{array}$ & $\begin{array}{c}2014 \\
\text { season }\end{array}$ & $\begin{array}{c}2013 \\
\text { season }\end{array}$ & $\begin{array}{c}2014 \\
\text { season }\end{array}$ & $\begin{array}{c}2013 \\
\text { season }\end{array}$ & $\begin{array}{c}2014 \\
\text { season }\end{array}$ & $\begin{array}{c}2013 \\
\text { season }\end{array}$ & $\begin{array}{c}2014 \\
\text { season }\end{array}$ \\
\hline \multicolumn{2}{|c|}{ Nitrogen rates } & \multicolumn{8}{|c|}{ Effect of nitrogen rates (kg N/fad.) } \\
\hline \multirow{3}{*}{\multicolumn{2}{|c|}{$\begin{array}{l}40 \mathrm{~kg} / \text { fad. } \\
60 \mathrm{~kg} / \text { fad. } \\
80 \mathrm{~kg} / \text { fad. }\end{array}$}} & 44.09 & 43.20 & 8.81 & 8.88 & 8.61 & 8.24 & 10.97 & 10.81 \\
\hline & & 45.24 & 46.24 & 9.30 & 9.43 & 9.29 & 9.51 & 10.43 & 10.29 \\
\hline & & 50.39 & 50.87 & 7.64 & 7.80 & 7.95 & 7.73 & 9.38 & 9.31 \\
\hline \multicolumn{2}{|c|}{ Whey protein (\%) } & \multicolumn{8}{|c|}{ Effect of whey protein rates (\%) } \\
\hline \multicolumn{2}{|c|}{0.0} & 44.02 & 43.31 & 8.01 & 8.02 & 7.95 & 7.71 & 9.73 & 9.81 \\
\hline \multicolumn{2}{|l|}{$0.05(\%)$} & 45.73 & 46.08 & 8.65 & 8.64 & 8.58 & 8.60 & 9.89 & 10.14 \\
\hline \multicolumn{2}{|l|}{$0.10(\%)$} & 47.59 & 48.30 & 8.75 & 8.94 & 8.89 & 8.78 & 10.61 & 10.20 \\
\hline \multicolumn{2}{|l|}{$0.15(\%)$} & 48.95 & 49.40 & 8.92 & 9.22 & 9.05 & 8.89 & 10.81 & 10.40 \\
\hline \multicolumn{2}{|c|}{ LSD at $5 \%$ level } & 2.01 & 2.57 & 0.54 & 0.47 & 0.37 & 0.46 & NS & NS \\
\hline \multicolumn{4}{|c|}{ Nitrogen ratesWhey protein } & \multicolumn{4}{|c|}{ Effect of interaction treatments } & & \\
\hline \multirow{3}{*}{40 kg /fad. } & $0.05(\%)$ & 42.49 & 42.46 & 8.92 & 8.65 & 8.55 & 8.60 & 10.76 & 10.85 \\
\hline & $0.10(\%)$ & 46.2 & 45.22 & 8.78 & 9.08 & 8.85 & 8.30 & 11.23 & 11.03 \\
\hline & $0.15(\%)$ & 47.04 & 45.34 & 9.04 & 9.47 & 9.08 & 8.20 & 11.63 & 11.14 \\
\hline \multirow[t]{4}{*}{60 kg /fad. } & 0.0 & 43.93 & 42.57 & 8.35 & 8.43 & 8.03 & 8.03 & 10.09 & 10.17 \\
\hline & $0.05(\%)$ & 45.43 & 46.21 & 9.24 & 9.59 & 9.34 & 9.81 & 9.92 & 10.36 \\
\hline & $0.10(\%)$ & 45.43 & 47.03 & 9.70 & 9.75 & 9.80 & 9.97 & 10.91 & 10.29 \\
\hline & $0.15(\%)$ & 46.17 & 49.16 & 9.90 & 9.96 & 10.00 & 10.23 & 10.79 & 10.33 \\
\hline \multirow[t]{4}{*}{80 kg /fad. } & 0.0 & 47.5 & 47.58 & 7.17 & 7.33 & 7.85 & 7.22 & 8.84 & 9.04 \\
\hline & $0.05(\%)$ & 49.27 & 49.56 & 7.80 & 7.68 & 7.85 & 7.40 & 8.98 & 9.21 \\
\hline & $0.10(\%)$ & 51.14 & 52.64 & 7.77 & 7.98 & 8.01 & 8.08 & 9.70 & 9.27 \\
\hline & $0.15(\%)$ & 53.65 & 53.71 & 7.83 & 8.22 & 8.08 & 8.23 & 10.01 & 9.73 \\
\hline \multicolumn{2}{|c|}{ LSD at $5 \%$ level } & 3.49 & 4.47 & 0.94 & 0.83 & 0.65 & 0.79 & 0.42 & 0.56 \\
\hline
\end{tabular}


Table 6. Effect of nitrogen rates, whey protein and their interactions on weight loss (\%) in tuber roots of sweet potato during storage period of 2013 and 2014 seasons

\begin{tabular}{|c|c|c|c|c|c|c|c|c|c|}
\hline \multirow{4}{*}{\multicolumn{2}{|c|}{ Treatments }} & \multicolumn{8}{|c|}{ Weight loss (\%) } \\
\hline & & \multicolumn{8}{|c|}{ Days from storage } \\
\hline & & \multicolumn{2}{|c|}{30} & \multicolumn{2}{|c|}{60} & \multicolumn{2}{|c|}{90} & \multicolumn{2}{|c|}{120} \\
\hline & & $\begin{array}{c}2013 \\
\text { season }\end{array}$ & $\begin{array}{c}2014 \\
\text { season }\end{array}$ & $\begin{array}{c}2013 \\
\text { season }\end{array}$ & $\begin{array}{c}2014 \\
\text { season } \\
\end{array}$ & $\begin{array}{c}2013 \\
\text { season }\end{array}$ & $\begin{array}{c}2014 \\
\text { season } \\
\end{array}$ & $\begin{array}{c}2013 \\
\text { season }\end{array}$ & $\begin{array}{c}2014 \\
\text { season }\end{array}$ \\
\hline \multicolumn{2}{|c|}{ Nitrogen rates } & \multicolumn{8}{|c|}{ Effect of nitrogen rates (kg N/fad.) } \\
\hline \multicolumn{2}{|c|}{40 kg /fad. } & 9.30 & 9.67 & 17.88 & 21.83 & 34.43 & 38.56 & 45.11 & 45.31 \\
\hline \multicolumn{2}{|l|}{$60 \mathrm{~kg} / \mathrm{fad}}$. & 7.01 & 7.73 & 13.73 & 17.00 & 26.58 & 32.45 & 38.35 & 38.68 \\
\hline \multicolumn{2}{|l|}{80 kg/fad. } & 9.37 & 8.81 & 17.85 & 20.14 & 36.07 & 36.38 & 52.52 & 52.33 \\
\hline \multicolumn{2}{|c|}{ LSD at $5 \%$ level } & 0.48 & 0.78 & 0.79 & 1.63 & 0.98 & 1.61 & 2.06 & 1.96 \\
\hline \multicolumn{2}{|c|}{ Whey protein (\%) } & \multicolumn{8}{|c|}{ Effect of whey protein rates (\%) } \\
\hline \multicolumn{2}{|l|}{$\mathbf{0 . 0}$} & 9.51 & 10.35 & 18.62 & 21.21 & 35.48 & 39.60 & 53.91 & 52.08 \\
\hline \multicolumn{2}{|l|}{$0.05(\%)$} & 8.95 & 9.33 & 17.13 & 21.36 & 33.69 & 37.28 & 45.92 & 46.33 \\
\hline \multicolumn{2}{|l|}{$0.10(\%)$} & 8.31 & 8.16 & 15.47 & 18.84 & 30.58 & 33.83 & 42.05 & 43.37 \\
\hline \multicolumn{2}{|l|}{$0.15(\%)$} & 7.47 & 7.11 & 14.72 & 17.21 & 29.68 & 32.48 & 39.42 & 39.97 \\
\hline \multicolumn{2}{|c|}{ LSD at $5 \%$ level } & 0.37 & 0.48 & 0.71 & 1.14 & 0.86 & 1.42 & 2.65 & 1.71 \\
\hline Nitrogen ra & Whey protein & \multicolumn{8}{|c|}{ Effect of interaction treatments } \\
\hline \multirow[t]{4}{*}{$40 \mathrm{~kg} / \mathrm{fad}}$. & 0.0 & 10.32 & 11.24 & 21.07 & 23.08 & 39.31 & 41.36 & 58.55 & 56.24 \\
\hline & $0.05(\%)$ & 9.28 & 10.04 & 18.64 & 23.76 & 33.57 & 40.09 & 43.83 & 44.88 \\
\hline & $0.10(\%)$ & 8.72 & 9.28 & 16.44 & 20.65 & 32.47 & 38.02 & 39.44 & 43.91 \\
\hline & $0.15(\%)$ & 8.88 & 8.12 & 15.36 & 19.82 & 32.36 & 34.77 & 38.63 & 36.19 \\
\hline \multirow[t]{4}{*}{60 kg /fad. } & 0.0 & 7.83 & 8.80 & 13.65 & 17.59 & 27.95 & 35.93 & 45.22 & 44.19 \\
\hline & $0.05(\%)$ & 7.83 & 8.43 & 15.29 & 19.03 & 29.50 & 34.94 & 39.27 & 40.19 \\
\hline & $0.10(\%)$ & 6.68 & 7.40 & 13.52 & 17.09 & 24.63 & 29.83 & 35.29 & 35.90 \\
\hline & $0.15(\%)$ & 5.68 & 6.29 & 12.46 & 14.29 & 24.25 & 29.09 & 33.62 & 34.42 \\
\hline \multirow[t]{4}{*}{80 kg /fad. } & 0.0 & 10.37 & 11.01 & 21.14 & 22.95 & 39.17 & 41.51 & 57.97 & 55.81 \\
\hline & $0.05(\%)$ & 9.73 & 9.52 & 17.47 & 21.30 & 38.01 & 36.80 & 54.67 & 53.93 \\
\hline & $0.10(\%)$ & 9.52 & 7.79 & 16.46 & 18.79 & 34.65 & 33.63 & 51.43 & 50.29 \\
\hline & $0.15(\%)$ & 7.85 & 6.92 & 16.34 & 17.51 & 32.43 & 33.59 & 46.01 & 49.29 \\
\hline \multicolumn{2}{|c|}{ LSD at $5 \%$ level } & 0.65 & 0.72 & 1.22 & 1.98 & 1.49 & 2.47 & 4.60 & 2.97 \\
\hline
\end{tabular}


Table 7. Effect of nitrogen rates, whey protein and their interactions on decay (\%) in tuber roots of sweet potato during storage period of 2013 and 2014 seasons

\begin{tabular}{|c|c|c|c|c|c|c|c|c|c|}
\hline \multirow{4}{*}{\multicolumn{2}{|c|}{ Treatments }} & \multicolumn{8}{|c|}{ Decay (\%) } \\
\hline & & \multicolumn{8}{|c|}{ Days from storage } \\
\hline & & \multicolumn{2}{|c|}{30} & \multicolumn{2}{|c|}{60} & \multicolumn{2}{|c|}{90} & \multicolumn{2}{|c|}{120} \\
\hline & & $\begin{array}{c}2013 \\
\text { season }\end{array}$ & $\begin{array}{c}2014 \\
\text { season }\end{array}$ & $\begin{array}{c}2013 \\
\text { season }\end{array}$ & $\begin{array}{c}2014 \\
\text { season }\end{array}$ & $\begin{array}{c}2013 \\
\text { season }\end{array}$ & $\begin{array}{c}2014 \\
\text { season }\end{array}$ & $\begin{array}{c}2013 \\
\text { season }\end{array}$ & $\begin{array}{c}2014 \\
\text { season }\end{array}$ \\
\hline \multicolumn{2}{|l|}{ Nitrogen rates } & \multicolumn{8}{|c|}{ Effect of nitrogen rates (kg N/fad.) } \\
\hline \multicolumn{2}{|l|}{40 kg /fad. } & 0.00 & 0.00 & 1.59 & 1.60 & $5.59^{\circ}$ & 6.36 & 8.46 & 9.91 \\
\hline \multicolumn{2}{|l|}{$60 \mathrm{~kg} / \mathrm{fad}}$. & 0.00 & 0.00 & 1.42 & 1.49 & 4.32 & 4.09 & 6.24 & 7.36 \\
\hline \multicolumn{2}{|l|}{80 kg/fad. } & 0.00 & 0.00 & 1.56 & 1.67 & 5.56 & 7.15 & 9.37 & 10.31 \\
\hline \multicolumn{2}{|c|}{ LSD at $5 \%$ level } & -- & -- & NS & NS & 0.12 & 0.24 & 0.35 & 0.43 \\
\hline \multicolumn{2}{|c|}{ Whey protein (\%) } & \multicolumn{8}{|c|}{ Effect of whey protein rates (\%) } \\
\hline \multicolumn{2}{|l|}{0.0} & 0.00 & 0.00 & 1.74 & 1.72 & 6.06 & 6.85 & 9.81 & 10.78 \\
\hline \multicolumn{2}{|l|}{$0.05(\%)$} & 0.00 & 0.00 & 1.51 & 1.63 & 5.43 & 6.42 & 8.21 & 9.59 \\
\hline \multicolumn{2}{|l|}{$0.10(\%)$} & 0.00 & 0.00 & 1.48 & 1.50 & 4.79 & 5.51 & 7.32 & 8.75 \\
\hline \multicolumn{2}{|l|}{$0.15(\%)$} & 0.00 & 0.00 & 1.37 & 1.49 & 4.33 & 4.69 & 6.74 & 7.65 \\
\hline \multicolumn{2}{|c|}{ LSD at $5 \%$ level } & -- & -- & NS & NS & 0.12 & 0.22 & 0.30 & 0.39 \\
\hline Nitrogen rates & Whey protein & \multicolumn{8}{|c|}{ Effect of interaction treatments } \\
\hline \multirow[t]{4}{*}{$40 \mathrm{~kg} / \mathrm{fad}}$. & 0.0 & 0.0 & 0.0 & 1.80 & 1.64 & 6.66 & 8.16 & 11.04 & 11.97 \\
\hline & $0.05(\%)$ & 0.0 & 0.0 & 1.55 & 1.66 & 5.71 & 6.79 & 9.13 & 10.40 \\
\hline & $0.10(\%)$ & 0.0 & 0.0 & 1.56 & 1.54 & 5.45 & 5.70 & 7.04 & 9.14 \\
\hline & $0.15(\%)$ & 0.0 & 0.0 & 1.44 & 1.54 & 4.53 & 4.80 & 6.63 & 8.14 \\
\hline \multirow[t]{4}{*}{60 kg /fad. } & 0.0 & 0.0 & 0.0 & 1.66 & 1.67 & 4.69 & 4.47 & 6.85 & 7.94 \\
\hline & $0.05(\%)$ & 0.00 & 0.00 & 1.44 & 1.52 & 4.76 & 4.73 & 6.48 & 8.25 \\
\hline & $0.10(\%)$ & 0.00 & 0.00 & 1.34 & 1.42 & 4.09 & 3.84 & 6.00 & 7.24 \\
\hline & $0.15(\%)$ & 0.00 & 0.00 & 1.23 & 1.35 & 3.73 & 3.33 & 5.62 & 6.01 \\
\hline \multirow[t]{4}{*}{80 kg /fad. } & 0.0 & 0.0 & 0.0 & 1.75 & 1.86 & 6.83 & 7.91 & 11.55 & 12.43 \\
\hline & $0.05(\%)$ & 0.0 & 0.0 & 1.54 & 1.71 & 5.83 & 7.74 & 9.02 & 10.11 \\
\hline & $0.10(\%)$ & 0.0 & 0.0 & 1.53 & 1.54 & 4.84 & 6.99 & 8.93 & 9.88 \\
\hline & $0.15(\%)$ & 0.0 & 0.0 & 1.43 & 1.58 & 4.73 & 5.94 & 7.98 & 8.80 \\
\hline \multicolumn{2}{|c|}{ LSD at $5 \%$ level } & -- & -- & NS & NS & 0.21 & 0.39 & 0.53 & 0.68 \\
\hline
\end{tabular}




\section{REFERENCES}

AOAC (1995). Association of Official Agricultural Chemists. Official Systems of Analysis. $17^{\text {th }}$ Ed. AOAC, Wash., D.C.

Abdelbacki, A.M., S.H. Taha, M.Z. Sitohy, A.I. Abou Dawood, M.M. Abd-El Hamid and A.A. Rezk (2010). Inhibition of tomato yellow leaf curl virus (TYLCV) using whey proteins. Virology J., 7 (26):1-6.

Adler-Nissen, J. (1986). Enzymatic Hydrolysis of Food Proteins. Barking. UK: Elsevier Applied Science Publishers.

Al-Easily, I.A.S. (2002). Response of some sweet potato cultivars to different agricultural treatments under sandy soil conditions. M. Sc. Thesis, Fac. Agric. Zagazig Univ.

Al-Mughrabi, K.I. (2007). Suppression of phytophthora infestans in potatoes by foliar application of food nutrients and compost tea. Aust. J. Basic Appl. Sci., 1(4): 785-792.

Bergmeyer, H.U., K. Gawehn and M. Grassl (1974). In: Bergmeyer Hu (Ed.) Methods of Enzymatic Analysis, vol. 1. Academic Press, New York, 495-496.

Constantin, R.J., L.G. Jones, H.L. Hammett, T.P. Hernandez and C.G. Kahlich (1984). The response of three sweet potato cultivars to varying levels of Nitrogen. J. Ame. Soc. Hort. Soc., 109: 605-614.

De Gobba, C., F. Espejo-Carpio, L. Skibsted and J. Otte (2014). Antioxidant peptides from goat milk protein fractions hydrolysed by two commercial proteases. Inter. Dairy J., 39: $28-40$.

El-Sayed, A.S., A.A. Shindia and Z. Zaher (2012). L-Amino acid oxidase from filamentous fungi: Screening and optimization. Ann. Microbiol. 62(2): 773.

Erman, M., S. Demir, E. Ocak, S. Tufenkci, F. Oguz and A. Akkopru (2011). Effects of Rhizobium, arbuscular mycorrhiza and whey applications on some properties in chickpea (Cicer arietinum L.) under irrigated and rainfed conditions 1 -Yield, yield components, nodulation and AMF colonization. Field Crops Res., 122 (1): 14-24.
Essilfie, M. E. (2015). Yield and storability of sweet potato (Ipomoea batatas (L.) Lam.) as influenced by chicken manure and inorganic fertilizer. Ph.D. Thesis, Gana Univ., Gana.

Farzana, Y., R.Othman, K. Sijam and M.S.Saad (2007). Effect of PGPR inoculation on growth and yield of sweet potato. J. Biol. Sci., 7 (2): 421-424.

Fatideh, M.M. and M.H. Asil (2012). Onion yield, quality and storability as affected with different soil moisture and nitrogen regimes. South west J. Hort. Biol. Environ., 3(2): 145165.

Forsee, W.T.Jr. (1938). Determination of sugar in plant materials A photometeric method. Indus. Eng. Chem. Anal. Ed., 10:411-418.

Garo, G., A. Gedebo and K. Kena (2014). Combined effects of inorganic (NP) and farmyard manure (FYM) fertilizers on root yield and above ground biomass of sweet potato (Ipomoea batatas L.) at Delbo watershed Wolaita zone, Southern Ethiopia. J. Sci. Res. Rev., 3 (2): 28 - 33.

Gupta, M., U.K. Mazumdar, P. Gomathi and R.S. Kumar (2004). Antioxidants and free radical scavenging activities of (Ervatamia coronaria, stapf leaves). Iran J. Farm. Res., $2: 119-126$.

Ha, M., A.E. Bekhit, M. McConnell, M., S. Mason and A. Carne (2014). Fractionation of whey proteins from red deer (Cervus elaphus) milk and comparison with whey proteins from cow, sheep and goat milks. Small Ruminant Res., (120): 125-134.

Hartmink, A.E., S. Poloma and J.N.O. Sullivan (2001). Integrated nutrient management research with sweet potato at Hobu. In: Food Security in Papua New Guinea. R.M Bourke, M.G. Allen and J.G. Salisbury (Eds).ACIAR Proceedings No. 99, Canberra, 698-711.

Hay, R.K.M. and A.J. Walker (1989). An introduction of the physiology of crop yield, UK limited, 292.

Koller, H.R. (1972). Leaf area-leaf weight relationship in the soybean canopy. Crop Sci., 12: 180-183. 
Korhonen, H. and A. Pihlanto (2006). Bioactive peptides: Production and functionality. Inter. Dairy J., (16): 945-960.

Lerner, B.R. (2001). The Sweet Potato. Purdue University cooperative extension service. Vegetables HO-136. W. West Lafayette.

Manochehrifar, P. (2010). Effect of Salicylic Acid in Plants. Paper presented at $1^{\text {st }}$ symposium of new findings in Chemistry and engineering chemistry. Iran.

Marshall, N.D. (2004). Therapeutic applications of whey protein. Alt. Med. Rev., 9 (2):136156.

Mehrabian N., M.J. Arvin, G.H. Khajoie Nezhad and K. Maghsodi (2011). Effect of salisylic acid on growth, seed and forage yield of corn under field drought stress. Seed Plant Prod. J., 2 (1): 41-55.

Okpara, D.A., O.E. Okon and F. Ekeleme (2009). Optimizing nitrogen fertilization for production of white and orange-fleshed sweet potato in Southeast Nigeria. J. Plant Nut., 32 (5): 878-891.

Phillips, S.B. and J.G. Warren (2005). Nitrogen rate and application timing affected Buregard sweet potato yield and quality. Hort. Sci., 40 (1): 214-217.

Sadek, U.M.S. (2000). Studies on bio and chemical fertilization on sweet potato (Ipomoea batatas L.). M. Sc. Thesis, Fac. Agric., Mansoura Univ.
Saraswati, P. and A. Suparno (2015). Water use efficiency and yield of sweet potato as affected by nitrogen and potassium application. J. Agric. Sci., 7 (7):128-137.

Sarvesh, A. and T.P. Reddy (1988). Peroxidase, polyphenol oxidase, acid phosphatase and alkaline inorganic pyrophosphatase activities during leaf senescence in varieties of castor (Ricinus communis L.). Indian J. Exp. Biol. 26: 133-136.

Sikka L. (1982). Fertilizer and manure requirement of potato. Potato seed production for Africa. Nganga and shideler, Eds. Inter. Potato Center, An. Rep., 93.

Snedecor, G.W. and W.G. Cochran (1980). Statistical Methods. $7^{\text {th }}$ Ed., Iowa State Univ., Press, Ames., Iowa, USA.

Thivend, P. (1977). Use of whey in feeding ruminants: with particular reference to pollution problems. World Anim. Rev., 23: 20.

Thomson, T., G.S. Patel, K.S. Pandya, J.S. Dabhi and P. Yogesh (2015). Effect of plant growth substances and antioxidants on growth, flowering, yield and economics of garden pea (Pisum sativum L.) cV Bonneville. Inter. J. Farm Sci., 5 (1): 8-13.

Wettestein, D. (1957). Chlorophyll. Lethale under Submikroskopische Formwechsel der Plastiden. Exp. Cell Reso., 12: 427-506. 


\title{
تأثير التسميد النيتروجينى وبروتينات شرش اللبن المحللة بالإنزيمات على النمو، والإنتاجية ومضادات
}

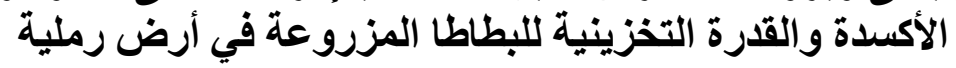

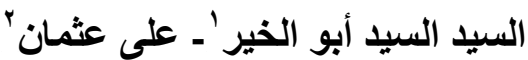

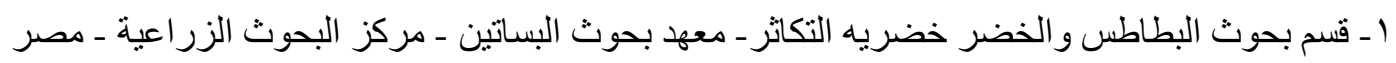

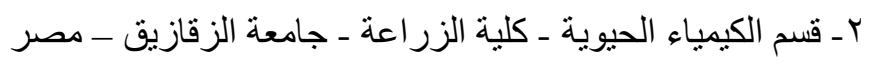

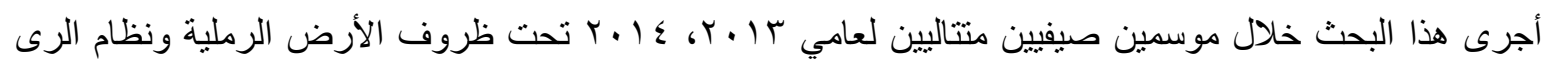

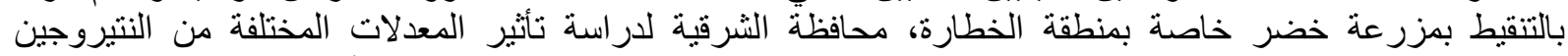

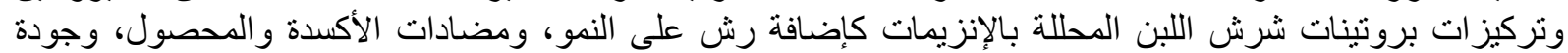

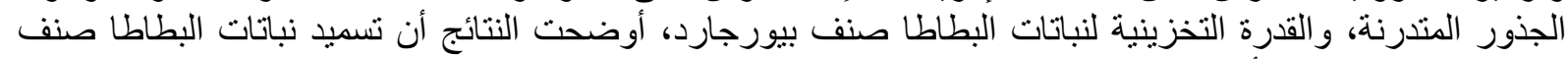

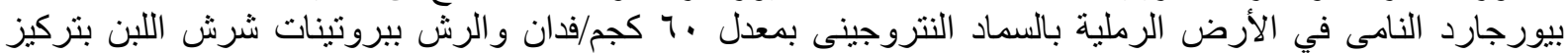

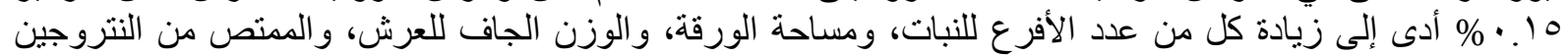

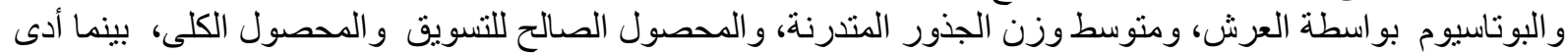

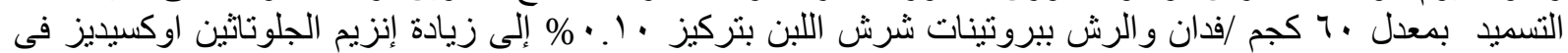

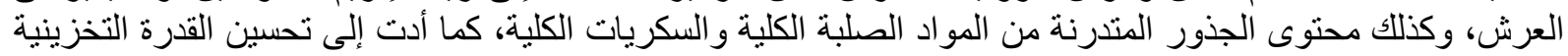

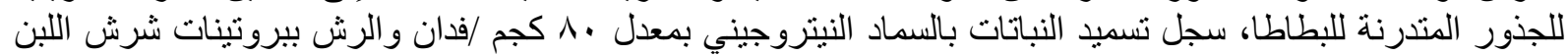

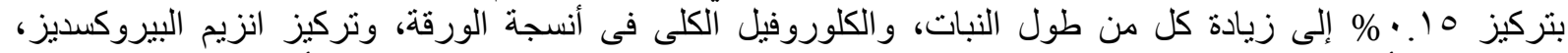

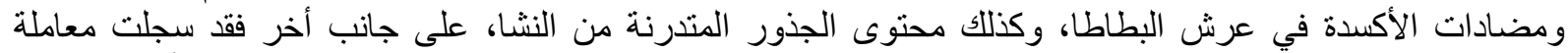

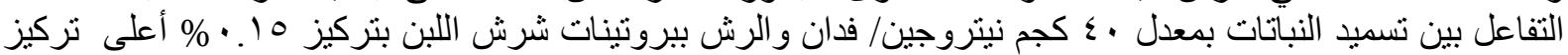

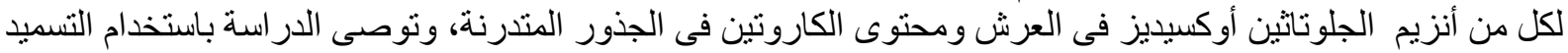

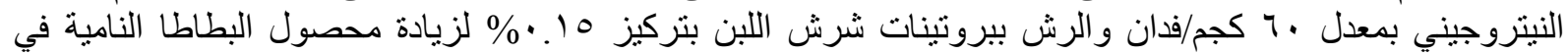

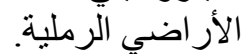

